\title{
MERUMUSKAN KERANGKA AKSIOMA ETIK ISLAM
}

\section{(Kajian Pemikiran Syed Nawab Haider Naqvi}

\section{dalam “Menggagas Ekonomi Islam”)}

Oleh: Jauhar Faradis

(Dosen Syariah UIN Sunan Kalijaga Yogyakarta)

\section{ABSTRACT}

Islamic ethic is representation of axioms that includes four elements namely, unity, equally, independent and responsibility. Ethics also meets all the principal characteristics of the axiom system: minimal, consistent, and independent. The device of this axiom also reflects the central message of the Islamic social philosophy is refusing of the status quo that is not fair and the demands of social change. Analysis used in this chapter is the use of ethical beliefs in a typical Muslim community as a valid logical basis of economic behavior.

Key words: Naqvi, Initiating, Economics, Islam.

\section{A. PENDAHULUAN}

Buku mengggagas ekonomi Islam karangan Syed Nawab Haidar Naqvi berbicara tentang rumusan kerangka aksioma etik Islam, Naqvi dalam bukunya banyak berbicara konsep-konsep ekonomi Islam dari segi etik, sehingga penulis merasa perlu untuk melakukan kajian ini.

\section{B. AGAMA SEBAGAI SUMBER AKSIOMA ETIK}

Al-Qur'an dan Sunnah Nabi merupakan sumber pokok etika Islam, yang dapat digunakan untuk menyimpulkan prinsip-prinsip umum prilaku ekonomi Islam. Hal ini menjadi penolakan terhadap status quo yang tidak berkeadilan, karena dalam Islam dianjurkan membantu menanamnya, pada level masyarakat, kesadaran untuk melaksanakan hak-hak moral individu, dan 
merekomendasikan dilakukannya tindakan koreksif ketika akibat-akibatnya secara sosial dan moral tidak dapat diterima.

\section{B.1 Karakteristik Sistem Aksioma Etik}

Seperangkat aksioma etik non-trivial minimal, artinya bahwa tidak ada perangkat yang dicirikan atau diisi oleh sesuatu yang bersifat nontrivial. Disamping itu, aksioma etik juga harus komprehensif untuk digunakan sebagai dasar yang memadai dalam merumuskan pernyataan ekonomi yang cukup banyak.

Untuk menghasilkan fungsi pernyataan-pernyataan ekonomi dengan tingkat generalitas, seperangkat aksioma etik Islam harus memenuhi sifat-sifat berikut:

1. Representasi pandangan yang memadai dan legitimate tentang etika Islam. Sifat ini bisa menghilangkan kesewenang-wenangan subyektif dalam memilih aksioma-aksioma etik, karena hanya yang memenuhi syarat saja (yang berasal dari Al-Qur'an dan Sunnah) yang bisa menjadi perangkat tersebut.

2. Suatu perangkat yang memadai, ia harus berbentuk 'suatu dasar'. Sifat ini dapat menghasilkan pernyataan ekonomi yang signifikan.

3. Independensi. Indenpendensi sistem aksioma matematika diperiksa dengan menetapkan independensi elemen-elemen satu dengan yang lainnya, yang dibuktikan dengan menunjukkan bahwa tidak ada eleman dalam perangkat itu, yang bisa dideduksi dari perangkat elemen lain dan elemen tersebut akan independen.

4. Semua elemennya harus konsisten satu sama lain. Menunjukkan bahwa tak satupun dari elemen dalam perangkat ini bisa dideduksi dengan cara sedemikian sehingga satu elemen bisa bertentangan (negation) dengan yang lain. Pengujian yang konsisten juga dapat dilakukan dalam pengertian yang lebih heuristik; bahwa kebenaran 
satu aksioma harus tidak mengingkari kebenaran aksioma lain dalam perangkat itu, dan masing-masing aksioma dalam perangkat tersebut harus menunjukkan kebenaran umum tentang sistem sebagai suatu keseluruhan.

5. Daya prediktifnya, yang mampu menghasilkan serangkaian elemen tunggal dari perangkat aksioma dasar. Secara empirik, elemenelemennya diharapkan dapat diverifikasi.

6. Harus memadai untuk mendeduksi seluruh penyataan dasar.

7. Bisa mengeluarkan keberadaan asumsi-asumsi yang tidak berguna.

\section{B.2 Efisiensi Sistem Aksioma Etik Islam}

Telah disebutkan di atas, bahwa perangkat itu tidak harus unik dalam arti satu-satunya yang memungkinkan untuk perumusan generalisasi yang valid tentang sistem ekonomi Islam; namun untuk mencapai tujuan yang ada, merupakan perangkat yang paling efisien. Suatu perangkat yang efisien merupakan keharusan sekaligus memadai untuk menghasilkan seluruh pernyataan ekonomi yang relevan dan memberikan pemahaman yang lebih mendalam terhadap fenomena ekonomi dalam masyarakat Islam.

Seperti yang sudah dijelaskan di atas bahwa aksioma tersebut bersifat independen satu sama lain. Dengan demikian, jika Kesatuan, merupakan dimensi vertikal, Kesejajaran merupakan dimensi horisontal, Kehendak Bebas, dapat melahirkan anarki terhadap harmonitas sosial, sedangkan Tanggung-jawab, jika didorong begitu jauh, dapat menjadi destruktif terhadap kebebasan manusia dengan demikian menjadi sumber Zulm (ketidaksejajaran). Dengan demikian, tidak ada satu pun elemen yang tidak bermanfaat, ke-empat elemen aksioma tersebut dibutuhkan sesuai dengan proporsinya. 
Perangkat itu konsisten dapat ditentukan dengan menunjukkan bahwa tidak mungkin menarik kesimpulan apapun darinya, sehingga kebenaran dari satu aksioma tidak bertentangan dengan aksioma lain dalam perangkat itu. Empat aksioma tersebut menyoroti sejumlah aspek penting dari filsafat etika Islam yang bertujuan untuk menghasilkan tatanan sosial ekonomis dan harmonis bagi manusia yang bebas, bertanggungjawab tidak hanya untuk meningkatkan kesejahteraan mereka sendiri tetapi juga kesejahteraan orang lain dalam masyarakat dan menuntut tidak hanya peningkatan kesejahteraan material, tetapi dalam kesejahteraan spiritual mereka. Dengan demikian, bahwa sistem aksioma etik dapat menambah pemahamana kita tentang hakekat sistem etika Islam.

\section{B.3 Menuju Ilmu Ekonomi Islam Normatif}

Prosedur untuk mendeduksi pernyataan-pernyataan ekonomi dari aksioma-aksioma etik, secara ilmiah merupakan prosedur yang benar dan juga mampu menghasilkan serangkaian hipotesis yang bisa diuji tentang ekonomi Islam. Ilmu ekonomi Islam mengantar kita untuk membahas masalah baru dan menggabungkan etika dan ekonomi ke dalam suatu frame-work tunggal. Juga ditawarkan frame-work analisis yang tepat terhadap masalah tersebut. Definisi ilmu ekonomi Robbins adalah ilmu yang mengkaji prilaku manusia sebagai suatu hubungan antara tujuan dan sarana yang terbatas yang memiliki kegunaan-kegunaan alternatife tampak terlalu sempit. Hal ini secara tegas membuang nilai etika sebagai sesuatu yang relevan untuk merumuskan pernyataan ekonomi hanya terbatas pada kajian tentang situasi-situasi konflik, situasi-situasi yang hakekatnya memang bersifat kompetitif.

Ilmu ekonomi Islam juga bersifat normatif dalam arti peka-dampak (consequence-sensitive) artinya ilmu konomi Islam tidak akan berlaku 
bagi aturan-aturan kebijakan (optimalitas pareto) yang menyetujui status quo meski hal itu merupakan realitas sosial yang tidak menguntungkan bagi kalangan yang miskin. Ia tidak hanya membahas masalah hak-hak kekayaan, tetapi juga menuntut Negara untuk mengambil sikap korektif jika pelaksanaan hak-hak kekayaan (pribadi) menimbulkan akibat sosial yang merugikan. Moralitas Islam menekankan baik kebebasan individu maupun tanggungjawab sosial secara sama. Disamping itu, Islam juga akan menolak teori-teori hak moral (moral righ theories) yang bersifat prosedural semata dan tidak peka-dampak (strictly procedural and concequence-intensitive), karena Islam menuntut hak-hak orang miskin atas kekayaan orang kaya dan memberikan tindakan (hukum) jika hakhak itu tidak diberikan pada orang miskin tepat pada waktunya.

Prosedur yang berangkat dari nilai etik ke ilmu ekonomi itu tidak harus mencemaskan kesadaran ilmuwan, karena dia harus menggunakan suatu sistem nilai yang tidak ditentukan sebelumnya sebagai rujukan dalam membuat pernyataan-pernyataan ilmiah. Dengan demikian, pencarian aturan-aturan kebijakan yang bebas nilai/etik adalah tidak berguna sekaligus kontrak-produktif bahkan dari sudut pandang ilmiah murni.

Berdasarkan karya Arrow, terdapat litelatur yang mengesankan tentang teori pilihan-publik (public-choice theory) yang menunjukkan bahwa keputusan-keputusan alternatife dapat diekspresikan dalam bentuk aksioma dan dapat dievaluasi berdasarkan implikasi-implikasi logisnya. Maka, model propabilitas Harsanyi didasarkan pada observasi bahwa masing-masing individu memiliki propabilitas yang sama untuk menjadi yang lain dalam masyarakat. Demikian juga, dalam model Rawlsian, person-person yang bebas dan sejajar secara khusus membuat suatu percobaan mental untuk mengambil keputusan imparsial untuk memilih 
institusi-institusi yang lebih fair. Tujuannya adalah untuk mengevaluasi kebaikan keadaan yang merujuk pada kesejahteraan individu-individu yang paling tidak sejahtera dalam masyarakat.

Perbedaan antara ilmu ekonomi (normatif) Islam dengan teori pilihan-publik adalah bahwa teori pilihan-publik tidak menerima agama sebagai wilayah untuk menggali nilai-nilai moral. Sebaliknya, bagi ilmu ekonomi Islam, agama merupakan tempat untuk mendapatkan prinsipprinsip Islam dasar.

\section{PENUTUP}

Dari kajian ini dapat disimpulkan bahwa Etika Islam representasi dari seperangkat aksioma yang mencakup empat elemen yaitu, Kesatuan, Kesejajaran, Kehendak Bebas dan Tanggungjawab. Perangkat nilai etik ini juga memenuhi seluruh karakteristik pokok sistem aksioma secara logis baik: minimal, konsisten, dan independen. Perangkat aksioma ini juga mencerminkan pesan sentral filsafat sosial Islam yaitu penolakan terhadap status quo yang tidak berkeadilan dan tuntutan terhadap perubahan sosial. Analisis yang digunakan dalam bab ini adalah penggunaan kepercayaan etik dalam masyarakat muslim yang khas sebagai dasar logis valid tentang perilaku ekonomi.

\section{DAFTAR PUSTAKA}

Naqvi, Haider. (2003) Menggagas Ilmu Ekonomi Islam, Yogyakarta: Pustaka Pelajar. Chapra, Muhammad Umer, 2001, Masa Depan Ilmu Ekonomi; Sebuah Tinjaun Islam, Cet. 1, Jakarta, Gema Insani Press bekerjasama dengan Tazkia Cendikia Mannan, M. Abdul, 1997, Teori dan Praktek Ekonomi Islam (Islamic Economic Theory and Practice), Yogyakarta: PT. Dana Bhakti Primayasa An-Nabhani, Taqyuddin. (2002) Membangun Sistem Ekonomi Alternatif Perspekrif Islam, Surabaya: Risalah Gusti 